\section{B A Institute of \\ YK Business Administration \\ 六下 \\ Karachi \\ Leadership and Ideas for Tomorrow}

Business Review

Volume 9 Issue 2 July-December 2014

$7-1-2014$

\title{
Perceived service quality of electricity supply in Nigeria: A survey of manufacturers in Kakuri Industrial Estate, Kaduna
}

\author{
Abdulsalam Dauda \\ Usmanu Danfodiyo Universit, Nigeria \\ Mohammed Abubakar Mawoli \\ Ibrahim Badamasi Babangida University, Nigeria \\ Abdullahi Yusuf Babandako \\ Ibrahim Badamasi Babangida University, Nigeria
}

Follow this and additional works at: https://ir.iba.edu.pk/businessreview

Part of the Operations and Supply Chain Management Commons

\section{(c) (9)}

This work is licensed under a Creative Commons Attribution 4.0 International License.

\section{Recommended Citation}

Dauda, A., Mawoli, M. A., \& Babandako, A. Y. (2014). Perceived service quality of electricity supply in Nigeria: A survey of manufacturers in Kakuri Industrial Estate, Kaduna. Business Review, 9(2), 133-142. Retrieved from https://doi.org/10.54784/1990-6587.1276

This article is brought to you by iRepository for open access under the Creative Commons Attribution 4.0 License and is available at https://ir.iba.edu.pk/businessreview/vol9/iss2/10. For more information, please contact irepository@iba.edu.pk. 
https://ir.iba.edu.pk/businessreview/vol9/iss2/10

DOI: https://doi.org/10.54784/1990-6587.1276

Business Review - Volume 9 Number 2

July - December 2014

\title{
ARTICLE
}

\section{PERCEIVED SERVICE QUALITY OF ELECTRICITY SUPPLY IN NIGERIA: A Survey Of Manufacturers In Kakuri Industrial Estate, Kaduna}

\author{
Abdulsalam Dauda \\ Usmanu Danfodiyo Universit, Nigeria. \\ Mohammed Abubakar Mawoli \\ Ibrahim Badamasi Babangida University, Nigeria \\ Abdullahi Yusuf Babandako \\ Ibrahim Badamasi Babangida University, Nigeria
}

\begin{abstract}
Manufacturing firms require adequate business support facilities in order to operate optimally and contribute to the economic growth of nations. The quality of the business support services is as important as their availability or provision. While it has been established that the existing business support services in Nigeria are inadequate, the quality of the existing business support facilities is unknown. Based on the contention that quality is determined by the user or customer, this study evaluates the service quality of electricity services in Nigeria from manufacturers' perception. The entire population of the study constituting the general managers and assistant managers of the thirteen (13) functioning manufacturing firms in the Kakuri Industrial Estate of Kaduna were surveyed cross-sectionally. A modified SERVQUAL scale with six (6) dimensions and twenty-seven (27)items was adopted in measuring the service quality of electricity supply to the industries. In the course of data analysis, descriptive statistics showed that the service quality of electricity services is poor for tangibility, reliability, responsiveness, assurance, empathy and recovery dimensions. Pearson correlation statistical tool applied to test hypothesis one revealed a significant negative association between expected and perceived service quality of electricity supplies ( $r=-.458 ; \alpha=.032)$, while Paired T-test used to test the hypothesis two indicated that there is significant negative difference between the industrialists' expected and perceived electricity services quality $(t=-9.720 ; \alpha=000)$. The study, therefore, recommends that the Nigerian government as well as stakeholders should ensure that the quality of electricity supplies in Nigeria is upgraded alongside the quantity (or megawatts) upsurge in the on-going power reforms in the country.
\end{abstract}

Key Words: Service Quality, Business Support, Electricity.

\section{Introduction}

Manufacturing firms are the economic nerve of every country. Their optimal operations depend on the quality of business support facilities such as electricity, water, and telecommunication among others. Though all business support facilities are essential for efficient operation of manufacturing firms, certain business support facilities are fundamental to their survival. It has been established that manufacturing sectors in Nigeria depend more on 
electricity than other infrastructures such as water, road, telephone and communication in order to operate efficiently (Adepoju and Abubakar, 2010). This tends to suggest that adequate provision of electricity on consistent basis in Nigeria will enhance industrialization and its attendant benefits.

However, the quality of the electricity services is as important as their availability. While it has been established that the quantity (in terms of megawatts) of electricity supply in Nigeria is grossly inadequate (see for example AFDB/OECD 2004; and Ajanaku, 2007), the service quality of the electricity services in the country or any of its parts is, to the best of our knowledge, unknown. There is a general consensus among marketing scholars that the quality of intangible products like public utilities can best be determined by the users or customers (Parasuraman et' al., 1985 and 1988; Cronin and Taylor, 1992; Tea, 1993). Based on this consensus that quality is determined by the users or customers, the service quality of public utilities like education, health, and telecommunications have been evaluated from customers perspectives in foreign countries like Japan, UK, Malaysia, and India, etc. (see: Nimsombood and Nagata, 2003; Pillay, 2004; Talib and Ali, 2007; Satish, 2009; Padhy et' al., 2009). In Nigeria, research on service quality is rather concentrated in the private sector of the economy, especially banking and telecommunication sectors (see: Mawoli, 2011; Oyeniyi, 2009; Abdullahi, 2009). Alabede et' al (2011) affirm that the issue of service quality was initially thought to be concept related only to the private sector but with systematic extension of the principles of marketing to public sector, it is now realized by organizations operating within the public sector that customer service and quality are strategic issue that desire attention. In the current study, therefore, focus is shifted to the investigation of the perceived service quality of electricity supply where a significant vacuum in knowledge still exists. The study therefore seeks to achieve the following objectives:

i. To determine manufacturers' expectation of each of tangibility, responsiveness, reliability, assurance, empathy, and recovery dimensions of electricity services provided by PHCN.

ii. To determine manufacturers' perception of each of tangibility, responsiveness, reliability, assurance, empathy, and recovery dimensions of electricity services provided by PHCN.

iii. To ascertain the service quality of electricity supply available to manufacturing firms.

iv. To determine the relationship between the service quality expectations and perceptions of electricity supply.

v. To investigate whether or not there is any significant difference between perceived and expected service quality of electricity supply.

The paper is organized in five sections namely: introduction; literature review; methodology; analysis and interpretations; and conclusions and recommendations.

\section{Literature Review}

Service quality refers to customers' attitude towards the service (Cronin and Taylor, 1992), which suggests that customers or service users are the best determinant and evaluators of the quality of a firm’s service. Thus, Gr $\square$ nroos (1984, P.25) defines service quality as the "outcome of an evaluation process, where the customers compare their expectations with the service they have received." In the same manner, Parasuraman et' al. (1985, P.48) define 
service quality as "a function of the difference between expectation and performance along the quality dimensions."

Service quality, in the context of electricity supply, is concerned with the availability of electricity when needed and on a safe and satisfactory operation of all connected electrical devices such as productive machinery and electronics (Sersen and Vorsic, 2009). The service quality of electricity supply constitutes the technical and commercial quality. The former relates to the continuity and/or reliability of the energy supply as well as the voltage quality. The latter is concerned with the services provided by the service provider (PHCN) to the consumers in terms of information on billing method, disconnection criteria, planned and unplanned power interruption, time for restoration of power, time for reconnection after debt repayment, time to respond to complaints, appearance of physical facilities, and appearance of staff, etc.

Out of several models developed for measuring consumer perception of service qualities, the most widely adopted model is SERVQUAL followed by SERVPERF. Parasuraman et al. 1985 and 1988) developed SERVQUAL model, while Cronin and Taylor (1992) developed SERVPERF model. Service quality is not viewed in literature as a separate construct, but rather as an aggregate of several dimensions or components (Suuroja, 2003). In literature, these dimensions are broadly categorized into five (5): tangibility, reliability, responsiveness, assurance and empathy - tagged as SERVQUAL. SERVQUAL instrument consists of a 22-item instrument for assessing service quality based on customer's perceptions, which is, by its turn, the difference between the customer perceived quality and his/her expectations [e.g. Expectation - Perception = Service Quality] (Miguel et' al., 2007). However, Cronin and Taylor (1992) adopted SEVQUAL 22-item and 7-points Likert Scale instrument to propose a perception-based service quality model called SERVPERF. The perceived quality model postulates that an individual's perception of the quality is only a function of the actual service performance and not service expectation.

Though research directed at investigating the state of service quality of private firms arguably outnumbered those of public or government enterprises, studies committed to assessment of service quality of the public enterprises are handy. Nimsomboon and Nagata (2003) revealed in their study that all the attributes of service quality did not meet the users' expectation of a public university in Japan. Similarly, Pillay (2004) empirically evaluated the service quality of an educational institution and found high expectations among students as against moderate perceptions, suggesting absence of service quality in the College. Satish (2009) measured the service quality of a public library in United Kingdom (UK) using SERVQUAL model and discovered that the library failed to match customers' experience with their anticipation and expectation in all dimensions, which portrays that service quality is severely lacking in the library. An attempt to evaluate the service quality of public banks in Indian by Padhy et al. (2009) revealed that the customers judge the reliability and responsiveness dimensions of service quality as poor. The study further revealed that both the rural and urban customers perceived the 'courtesy' dimension of the banks' service quality as poor, while the urban customers adjudged the 'tangibility' aspects of the public banks' service quality as superior. Jannadi et' al. (2000) measured the service quality of electricity supply company (SCECO-EAST) in Saudi Arabia by means of SERVQUAL and found that customers are pleased and satisfied with the overall service quality of the public utility. Cohen (n.d) adopted SERVQUAL to measure the service quality of electricity utility in Israel which was found to range from medium to high service quality. 
Service quality research is growing in large number because according to Zeithaml et' al. (1996), superior service quality often leads to retention, which leads to on-going revenue, increased spending, payment of price premiums, and generation of referred customers. However, studies that use service quality as the causal or independent variables have found missed results. Talib and Ali (2007) established that the existence of service quality in the public sector is responsible for overall positive performance of local authorities in Malaysia. A study by Buzell and Gale (1987) has shown a high correlation between relative product quality and company profitability. Cronin and Taylor (1992) found that service quality has significant effect on repurchase intentions. Oyeniyi and Joachim (2008) found a strong relationship between customers' perceived service quality level and customer satisfaction in the mobile phone industry in Nigeria. Alabede et' al. (2011) investigated the relationships between tax service quality and tax payers' compliance behavior in Nigeria and established that tax service quality has significant positive association with tax payers' compliance behavior.

\section{Methodology}

Primary data was obtained from a survey of managers of manufacturing firms in Kakuri industrial estate, Kaduna. The managers (e.g. the general manager and assistant manager) of each of the 13 functioning manufacturing firms in the industrial estate constitute the population of the study. Hence, the entire 26 managers were considered for the study. The companies' managers are arguably in the right position to describe the electricity service quality available to their firms.

The research variables were measured by means of modified SERVQUAL scale made up of 6 dimensions (i.e. tangibility, reliability, responsiveness, assurance, empathy, recovery) and 27 items. The scale is a 5-point Likert type, and ranges from Strongly Agreed (5) to Strongly Disagreed (1). Items under tangibility dimension are 'PHCN operates with latest technology', 'the physical facilities of PHCN are visually appealing', 'employees of PHCN are smartly and professionally dressed', and 'PHCN operational manuals are visually appealing'. Reliability items are 'PHCN provides uninterrupted electricity supply to customers at all time', 'PHCN provide electricity services right to the first time business users', 'PHCN restore all power failures within a short period', 'the voltage level of electricity supply by PHCN is high enough to power all factory and office machineries accordingly', 'the voltage level of electricity supply by PHCN is consistently normal and harmless to electrical appliances', 'PHCN provides electricity services to customers at the time it promises to do so', and 'PHCN insists on error-free billing records'. Statement items contained in responsiveness dimension are 'PHCN adequately inform customers about when electricity services will be provided or not', 'PHCN employees provide services to customers promptly', 'PHCN employees are ever ready and willing to help customers solve their problems', and 'PHCN employees are never to be too busy to attend to customers' problems'. The assurance dimension items are 'the behaviour of the PHCN employees instills confidence in customers', 'customers feel safe when transacting with the PHCN employees', 'PHCN employees are consistently polite to customers', and 'PHCN employees demonstrate adequate knowledge in providing answers to customers' questions'. For the empathy dimension, the items used are 'PHCN employees give customers individual attention', 'PHCN employees keep customers information confidential', 'PHCN employees have customers' interest at heart', and 'PHCN employees understand customers' specific needs'. Finally, the recovery dimension contains items such as 'PHCN employees quickly apologize to customer when 
mistakes are made', 'the company employees to care about customer's complaints', 'PHCN employees have the skills and ability to deal with complaints', and 'PHCN compensate customers who suffer damages from poor electricity services'.

The statistical instruments employed for data analysis are mean, standard deviation, Pearson correlation and paired t-test. In particular, Pearson correlation statistical tool was used to test hypothesis one, while paired t-test was employed to test hypothesis two. The paired-sample t-test procedure compares the means of 2 variables for a single group. The procedure computes the differences between values of the two variables for each case and test whether the average differs from ' 0 '. All statistical analyses are done by means of Social Science Statistical Package (SPSS) version 20 and at 95 percent confidence interval.

The following null hypotheses are tested in this study:

$\mathbf{H}_{01}$ : There is no statistically significant relationship between the expected service quality and perceived service quality of electricity.

$\mathbf{H}_{\mathbf{0 2}}$ : There is no statistically significant negative difference between the expected and perceived service quality of electricity.

\section{Analysis and Interpretation}

\section{Response Rate and Reliability Test}

A total of 26 copies of the questionnaire were distributed to the managers of 13 manufacturing firms in Kakuri industrial estate of Kaduna, Nigeria. However, only 22 copies of questionnaire equivalent to $84.6 \%$ were retrieved from 11 firms. Four copies of questionnaire equivalent to $15.4 \%$ were not returned.

The 'reliability' of the adopted SERVQUAL scales was determined using Cronbach's alpha method. Analysis revealed that electricity service quality's expectation scale is reliable by $90 \%$, and its perception scale by $68 \%$. (see table 1). Cronbach's alpha measures the average of measurable items and its correlation, and if the result is generally above 0.5 (or 50\%), it is considered to be reliable (see Peighambari, 2007). Hence, the data collected by means of the identified two scales are strongly reliable.

\section{Expectation and Perception of Electricity Service Quality}

From the outset of the study, it was considered essential to ascertain industrialists' expectation of electricity service quality. Data analysis revealed that the industrialists have a higher service quality expectation for reliability dimension (mean $=4.221$ or $84.4 \%$ ), followed by assurance dimension (mean $=4.205$ or $84.1 \%$ ), empathy (mean $=4.068$ or $81.4 \%$ ), recovery dimension (mean $=3.955$ or $79.10 \%)$, responsiveness dimension $($ mean $=$ 3.783 or $75.7 \%$ ), and tangibility dimension (mean $=3.438$ or $68.8 \%$ ), in the ascribed descending order. Overall, the expected service quality of electricity is relatively higher among the industrialists (e.g. grand mean $=3.942$ or $78.8 \%$ ).

On the contrary, the industrialists perceived the quality of electricity services rendered to them as poor (grand mean $=1.867$ or $37.3 \%$ ). Precisely, they rated the tangibility aspects of electricity services as better off (e.g. mean $=2.113$ or $42.3 \%$ out of total maximum score of 5). This is closely followed by responsiveness and empathy dimensions with mean value of 2.068 (or $41.4 \%$ ) and 2.000 (or $40 \%$ ) respectively out of a total mean score of 5 or $100 \%$. Other dimensions \{reliability, assurance, and recovery) are scored below $40 \%$. (Table 2 about here) 


\section{Service Quality of Electricity Supply}

The service quality of electricity supplies to the manufacturing industries was also investigated. Data analyses as contained in table 3 reveals a negative mean difference for all the 6 dimensions of service quality, which is an indication of poor electricity service quality in all the dimensions. Comparatively, the assurance dimension recorded poorest service quality (Mean difference $[\mathrm{MD}]=-2.605)$, followed by reliability dimension $(\mathrm{MD}=-2.391$ ), then recovery dimension $(\mathrm{MD}=-2.326)$, empathy dimension $(\mathrm{MD}=-2.068)$, responsiveness dimension ( $\mathrm{MD}=-1.715)$, and tangibility dimension $(\mathrm{MD}=-1.325)$ in the given descending order. Generally, the electricity service quality is poor ( $\mathrm{MD}=-2.078)$. (See Table 3 )

\section{Test of Hypotheses}

The null hypothesis one which states: "There is no statistically significant relationship between perceived and expected service quality of electricity" was tested using 'Pearson correlation'. The summary of the correlation analysis is contained in table 4, while the original computer generated output is the Correction Table in the appendix.

Table 4 shows that the paired variables (e.g. perception and expectation) are negatively correlated by as much as $46 \%$ (e.g. correlation $=-0.458$ ), and significant at $\mathrm{P}=$ $.032(<\mathrm{P}=.05)$. This suggests a moderate negative correlation, which further implies that, though the industrialists' expectation of electricity service quality is increasing, the actual service quality of electricity is decreasing instead. Therefore, the null hypothesis is not supported (there is statistically significant negative relationship between perceived and expected service quality of electricity).

The null hypothesis two which states that there is no statistically significant negative difference between the perceived and expected service quality of electricity was tested using 'paired sample t-test'. The summary of the t-test analysis is presented in table 4, while the original computer generated output is the Paired Sample test Table in the appendix. The table revealed a mean difference of -62.636 (e.g. Perception minus Expectation), t-value of -9.720 which is significant at $\mathrm{P}=.000$ (or $\mathrm{P}<0.01$ or $1 \%$ ). Thus, the null hypothesis which states that there is no statistically significant difference between industrialists' expectation and perception of electricity service quality is rejected, while the alternative hypothesis is supported. That is, there is statistically significant difference between perceived and expected service quality of electricity supply.

\section{Discussion of Findings}

The study evaluated the service quality of electricity supplies to the manufacturing industries in Kakuri industrial estate of Kaduna, Nigeria. The study found that the electricity service quality is poor along all the six service quality dimensions. This finding is consistent with prior studies on the service quality of public enterprises. For example, Nathan (2011) found that industrial and organization customers rated electricity services in India as poor, while domestic customers regarded it as satisfactory. In a related study, Satish (2009) established that the service quality of the examined public library in United Kingdom (UK) is poor.

Furthermore, the study established a significant negative correlation between expected and perceived service quality of electricity supplies. This implies that while the industrialists expected improvements in the service quality of electricity supplies, the perceived or actual service quality of electricity supplies is getting poorer. The perceived poor 
service quality of electricity is likely to affect the operational activities of the companies programmed productions could be interrupted, materials undergoing productions could be destroyed, factory machines could run bad, the chances of electricity-caused fire outbreaks within the factory could increase, production of substandard products, and increasing cost of production becomes inevitable. In the end, these manufacturing companies would be unable to compete favourable in the Nigerian market that is awashed with cheaply made and sold foreign goods and forced to adopt survival strategies (e.g. structural downsizing, staff retrenchment, leasing out facilities, and renting out plant factories) in the short run, and perhaps reverse to the growth strategies in the long-run when the electricity and other economic situations improve.

\section{Conclusions and Recommendations}

The study examined the service quality of electricity supplies to the manufacturers in Kakuri industrial estate of Kaduna State, Nigeria. It found that the manufacturers' expectations (needs) for electricity services from PHCN exceeded their perception or performance of the services for tangibility, reliability, responsiveness, assurance, empathy and recovery dimensions. The study also established that the service quality of electricity supply to the manufacturers in Kaduna State is poor. The study, therefore, concludes that there is poor service quality from PHCN as there is expectation and performance of service gap from the perspective of managers of these firms.

Furthermore, the study investigated the relationship between electricity-servicequality expectation and electricity-service-quality perception. The study established a negative correlation between electricity-service-quality expectation and electricity-servicequality perception. The study, therefore, concludes that as the manufacturing industries' needs for quality electricity supply rise, the actual quality of its supply diminishes in Kaduna, Nigeria.

Arising from the study findings and conclusions, the study recommends that the quality of electricity supplies should be improved in order to meet or exceed the needs of the manufacturing companies. Quality of electricity supplies is not restricted to increment of mega-watts of electricity as claimed by the Nigerian government ad PHCN, but transcends to electricity distribution, billing, customer care, customer relationships, and compensations aspects.

\section{References}

Abdullahi, S.A. (2009), An Assessment of the Perceived Service Quality of Global System for Mobile (GSM) Network by Subscribers in the Federal Capital Territory, Abuja-Nigeria, Lapai International Journal of Management and Social Sciences, Vol. 2, No. 2, pp. 285-301.

Adepoju, B.A. and Abubakar, Y. (2009), State of Infrastructural Facilities and Operational and Operational Efficiency of Manufacturing Industries in Kano Metropolis, Nigeria, Nigerian Academy of Management Journal, Vol. 3, No. 1, pp. 92-106

AFDB/OECD (2004), African Economic Outlok: Nigeria. Web-site: http://www.oecd.org/dataoecd/24/22.32430302.pdf. (9/3/2008)

Ajala, I. (2005), GIS and GSM Network Quality Monitoring: A Nigerian Case Study. Website: http://www.directionsmag.com/article.php?article_id=2030trv=1. $(15 / 7 / 2008)$. 
Alabede, J.O., Affrin, Z.B.Z. and Idris, K.M. (2011), Tax Service Quality and Compliance Behaviour in Nigeria: Do Taxpayer's Financial Condition and Risk Preference Play any Moderating Role? European Journal of Economics, Finance and Administration, Issue 35.

Buzzel, R.D. and Gale, B.T. (1987), The PIMS Principles: Linking Strategy to Performance, New York: Free Press.

Cohen, H. (n.d), Measuring Service Quality of Public Organization in Israel Using SERVQUAL Model: A Case study. Web-site: http://www.medeu.org/proceedings/MED2/COHEN\%20Haim.pdf (1/1/2012).

Cronin, J.J. and Taylor, S.A. (1992), Measuring Service Quality: A Re-examination and Extension, Journal of Marketing, Vol. 56, No. 3, pp. 55-68.

Gronroos, C. (1984a), Service Quality - Main Conceptualization and Critique. Website: http://papers.ssrn.com/S013/papers.Cfm?abstract_id=486947. (13/09/2008)

Jannadi, O.A., Assaf, S., Maghraby, H. and Al-saghal, H.A. (2000), Service Quality Gaps analysis in SCECO-EAST, Saudi Arabia, Journal of Energy Engineering, Vol. 126, No. 3, pp. 116-131. Web-site: http://dx.doi.org/10.1061/(ASCE)0733-9402(2000)126:3(116). $(1 / 1 / 2012)$.

Mawoli, M.A. (2011), Effects of Service Quality on Consumer Patronage of GSM Service Providers, MSc Dissertation Submitted to the Department of Business Administration, Bayero University Kano.

Miguel, P.A.C, Terra da Silva, M., Chiosini, E.L. and Schutzer, K. (2007), Assessment of Service Quality Dimensions: a Study in a Vehicle Repair Service Chain. Website: http://www.poms.orgkonrences/cso2007/talks/36.pdf (20/4/2009).

Nathan, S. (2011), Service Quality in Power Sector, Bachelor of Technology Thesis in the Department of Mechanical Engineering, National Institute of Technology, Rourkela. Website:

http://ethesis.nitrkl.ac.in/2342/1/Service_Quality_in_Power_Sector_\%28Senthil_Nathan\%2C 107ME054\%29.pdf (1/12/2012).

Nimsomboon, N. and Nagata, H. (2003), Assessment of Library Service Quality at Thammasat University Library System. Web-site: http:www.tsukkuba.ac.jp/divcomm/pdf/report0403.pdf

Oyeniyi, O. (2009), Measuring Service Quality in Nigerian Telecommunication Industry, Lapai International Journal of Management and Social Sciences, Vol. 2, No. 1, pp. 143-152.

Oyeniyi, O. and Joachin, A.A. (2008), Customer Service in the Retention of Mobile Phone Users in Nigeria, African Journal of Business Management, Vol. 2, No. 2, pp. 026-031. Website: http://www.academicjournals.org/AJBM. (11/10/2008)

Padhy, P.K. and Swar, B.N. (2009), A Study on Customer Satisfaction and Service Gaps in Selected Private, Public and Foreign Banks. Web-site: http://ssrn.com/abstract=1525555. (12/12/2009).

Parasuraman, A., Zeithaml, V.A. and Berry, L.L. (1985), A Conceptual Model of Service Quality and its Implications for Future Research, Journal of Marketing, Vol. 49, pp. 41-50. 
(1988), SERVQUAL: A Multi-Item Scale for Measuring Consumer Perception of Service Quality, Journal of Retailing, Vol. 64, No. 1, pp. 140-147.

Pillay, T.E. (2004), Towards Conceptualization of service Quality at an Educational Institution, Being Masters in Business Administration's Thesis for Submitted to Graduate School of Business, University of Kwazul-Natal, Durban. Web-Site: http://researchspace.wkzn.ac.za./xmlui/bitstream/handle/10413/1705/pillay-ThevanEkambaram-2004.pdf? sequence $=1$

Satish, V. (2009), Students Perception of Service Quality of Chester Seaborne Library, Being an MBA Dissertation Submitted to University of Chester. Web-site: http://chesterep.openrepository.com/cdr/bitstream/10034/100056/1/satish\%/20Velayudhan.pd f $(3 / 3 / 2011)$

Suuroja, M. (2003), Service Quality - Main Conceptualization and Critique. Website: http://papers.ssrn,com/So13/papers.cfm?abstract_id=486947. (13/09/2008).

Talib, D. and Ali, K.A.M. (2007), An Empirical Study on the Effects of Service Quality towards Organizational Performance in Malaysian Local Authorities. Web-site: http://www.jgbm.org/page/8\%20talib.pdf (6/9/2011)

Teas, R.K. (1993), Expectation, Performance Evaluation and Customer's Perception of Quality, Journal of Marketing, Vol. 57, Issue 4, pp. 18-34.

Zeithaml, V.A., Bitner, M.J. and Gremler, D.D. (2006), Service Marketing: Integrated Customer Focus across the Firm (4 ${ }^{\text {th }}$ Ed.), New York: McGraw-Hill.

\section{APPENDIX}

Table 1: Reliability Coefficients of the Measurement Scales

\begin{tabular}{|c|c|c|}
\hline Scale & Number of items & Cronbach's Alpha \\
\hline Expectation & 27 & .901 \\
\hline Perception & 27 & .682 \\
\hline
\end{tabular}

Source: Researchers' Computation, 2012

Table 2: Perceived and Expected Service Quality of Electricity Supply

\begin{tabular}{|c|c|c|c|c|c|c|}
\hline \multirow{2}{*}{ Dimension } & \multicolumn{3}{|c|}{ Perception } & \multicolumn{3}{c|}{ Expectation } \\
\cline { 2 - 7 } & Mean & $\begin{array}{c}\text { Std. } \\
\text { Deviati } \\
\text { on }\end{array}$ & $\begin{array}{c}\text { Ranking } \\
\text { (based on } \\
\text { mean score) }\end{array}$ & Mean & $\begin{array}{c}\text { Std. } \\
\text { Deviat } \\
\text { ion }\end{array}$ & $\begin{array}{c}\text { Ranking } \\
\text { (based on } \\
\text { mean score) }\end{array}$ \\
\hline Tangibility & 2.113 & .462 & 1 & 3.438 & .874 & 6 \\
\hline Reliability & 1.830 & .760 & 4 & 4.221 & .665 & 1 \\
\hline Responsiveness & 2.068 & .971 & 2 & 3.783 & .960 & 5 \\
\hline Empathy & 2.000 & .670 & 3 & 4.068 & .342 & 3 \\
\hline Assurance & 1.600 & .433 & 5 & 4.205 & .616 & 2 \\
\hline Recovery & 1.593 & .424 & 6 & 3.955 & .557 & 4 \\
\hline Grand mean & $\mathbf{1 . 8 6 7}$ & & & $\mathbf{3 . 9 4 5}$ & & \\
\hline
\end{tabular}

Source: Field Survey, 2012 
Business Review - Volume 9 Number 2

Table 3: Service Quality of Electricity Supply

\begin{tabular}{|c|c|c|c|c|}
\hline Dimension & Perception & Expectation & $\begin{array}{c}\text { Service quality } \\
\text { (Mean difference) }\end{array}$ & $\begin{array}{c}\text { Ranking } \\
\text { of Service quality }\end{array}$ \\
\hline Tangibility & 2.113 & 3.438 & -1.325 & 1 \\
\hline Reliability & 1.830 & 4.221 & -2.391 & 5 \\
\hline Responsiveness & 2.068 & 3.783 & -1.715 & 2 \\
\hline Empathy & 2.000 & 4.068 & -2.068 & 3 \\
\hline Assurance & 1.600 & 4.205 & -2.605 & 6 \\
\hline Recovery & 1.593 & 3.955 & -2.326 & 4 \\
\hline Grand mean & $\mathbf{1 . 8 6 7}$ & $\mathbf{3 . 9 4 5}$ & $\mathbf{- 2 . 0 7 8}$ & \\
\hline
\end{tabular}

Source: Field Survey, 2012

Table 4: Summary of Correlation and Paired t-test Analysis

\begin{tabular}{|l|c|}
\hline Statistics & Results \\
\hline Correlation $(r)$ & $-.458(\mathrm{P}<0.05)$ \\
\hline Significance level of 'r' & $.032^{*}$ \\
\hline Mean difference & -62.636 \\
\hline t-test & -9.720 \\
\hline Significance level of 't-test' & $.000 * *(\mathrm{P}<.01)$ \\
\hline
\end{tabular}

* Significant

**Highly significant

Source: Field Survey, 2012

\begin{tabular}{|ll|r|r|}
\hline \multicolumn{2}{|c|}{ Correlations } \\
\hline & & PERCEPTION & EXPECTATN \\
\hline PERCEPTION & Pearson Correlation & 1 & $-.458^{*}$ \\
& Sig. (2-tailed) & & .032 \\
& $\mathrm{~N}$ & 22 & 22 \\
\hline EXPECTATN & Pearson Correlation & $-.458^{*}$ & 1 \\
& Sig. (2-tailed) & .032 & \\
& $\mathrm{~N}$ & 22 & 22 \\
\hline
\end{tabular}

${ }^{*}$. Correlation is significant at the 0.05 level (2-tailed).

\begin{tabular}{|ll|r|r|r|c|}
\multicolumn{8}{|c|}{ Paired Samples Statistics } \\
\hline & & Mean & N & Std. Deviation & $\begin{array}{c}\text { Std. Error } \\
\text { Mean }\end{array}$ \\
\hline Pair & PERCEPTION & 55.45 & 22 & 16.437 & 3.504 \\
1 & EXPECTATN & 118.09 & 22 & 18.926 & 4.035 \\
\hline
\end{tabular}

Paired Samples Correlations

\begin{tabular}{|ll|r|r|r|}
\hline & & $\mathrm{N}$ & Correlation & \multicolumn{1}{c|}{ Sig. } \\
\hline $\begin{array}{l}\text { Pair } \\
1\end{array}$ & $\begin{array}{l}\text { PERCEPTION \& } \\
\text { EXPECTATN }\end{array}$ & 22 & -.458 & .032 \\
\hline
\end{tabular}

Paired Samples Test

\begin{tabular}{|c|c|c|c|c|c|c|c|c|c|}
\hline & \multicolumn{5}{|c|}{ Paired Differences } & \multirow[b]{3}{*}{$t$} & \multirow[b]{3}{*}{ df } & \multirow[b]{3}{*}{ Sig. (2-tailed } \\
\hline & & \multirow[b]{2}{*}{ Mean } & \multirow[b]{2}{*}{ Std. Deviation } & \multirow{2}{*}{$\begin{array}{l}\text { Std. Error } \\
\text { Mean }\end{array}$} & \multicolumn{2}{|c|}{$\begin{array}{l}95 \% \text { Confidence } \\
\text { Interval of the } \\
\text { Difference }\end{array}$} & & & \\
\hline & & & & & Lower & Upper & & & \\
\hline $\begin{array}{l}\text { Pair } \\
1\end{array}$ & $\begin{array}{l}\text { PERCEPTION } \\
\text { EXPECTATN }\end{array}$ & -62.636 & 30.225 & 6.444 & -76.038 & -49.235 & -9.720 & 21 & .000 \\
\hline
\end{tabular}

